ALEKSANDAR MEDOVIĆ

Museum of Vojvodina,

Novi Sad, Serbia

arheolog2@gmail.com
902.2:633.17(497.11)

904:633.17”652”(497.11)

COBISS.SR-ID 212291596

Original research article

Received: March 22nd 2013

Accepted: February 15th 2014

\title{
VIMINACIUM: ROMAN AGRICULTURE ON SERBIAN SOIL?
}

\begin{abstract}
If our aim is to provide visitors of the Archeological park Viminacium an aura of Roman way of life, it would be certainly in our interest to revive a piece of Roman agriculture as well. This isn't possible if the park area is covered with crop that came to Serbia at the end of $16^{\text {th }}$ cent. AD - maize. Archaeobotanical research can help us determine ancient crops which were sawn on the fertile fields of this Roman town and military camp.
\end{abstract}

Keywords: Viminacium, Archaeological park, tourism, archaeobotany, local farmers, ancient plant economy.

When visitors of Viminacium pass the welcome gate of the Archaeological park next to Kostolac Power plant, they will be confronted with vast maize fields for almost $2 \mathrm{~km}$ until they finally reach parking area in front of the "Mausoleum" (Fig. 1). This isn't surprising if we know that maize was sawn on the half of the spring sowing area in Serbia in 2012, on almost 1.3 million of hectare, which represents one quarter of all arable land in the country.

First records of maize in Serbia go back to 1576 (Zirojević 2006). It was introduced to Balkans and south Central Europe via "Turkey" and North Africa. In central Europe it was known as "türkischer Weizen" (Germ.), or "grano turco" (Ital.). At the beginning it was grown in gardens. In an Ottoman letter from $17^{\text {th }}$ century it was mentioned that the maize was cultivated at Kosmaj Mountain near Belgrade, which is 60 $\mathrm{km}$ south-west from Viminacium. Already in 1718 , in Belgrade's surrounding one third of the plough land was cultivated by maize. But, all this has nothing to do with Viminacium, nor Roman plant husbandry. If our aim is to provide visitors of the park an aura of Roman way of life, it would be certainly in our interest to revive a piece of Roman agriculture as well. Is it possible?

Until recently, very little was known about the agriculture of the antique period in Serbia. At the beginning of the $21^{\text {st }}$ century two archaeologists have recognized the problem regarding the lack of botanical data for that period. They tried to reconstruct Roman plant husbandry in the Bal-

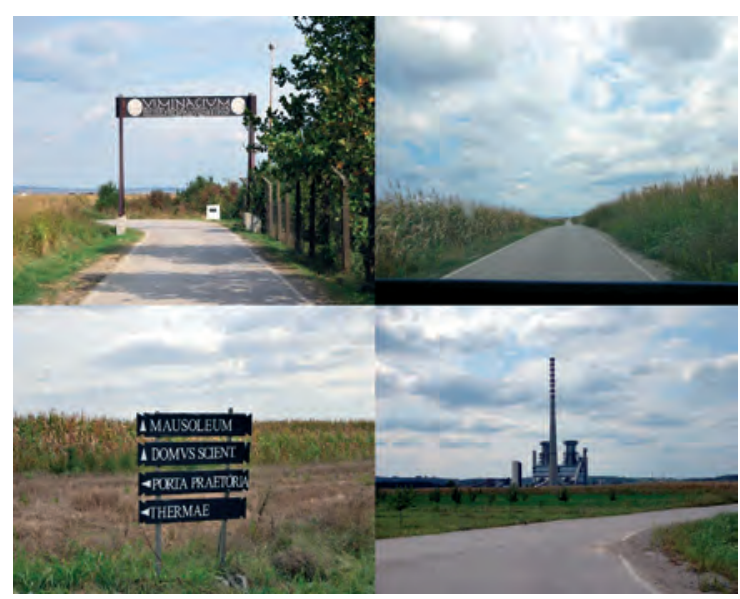

Fig. 1 Photos of the Archaeological park Viminacium taken by the visitors posted on one of the internet forums 
kans according to archaeobotanical records from Europe north of Alps (Tapavički-Ilić \& Arsenijević 2006). As Virgil in $29 \mathrm{BC}$ in his The Georgics wrote: "Not that all soils can all things bear alike" and as crops are regionally adapted to climate such comparison is inappropriate. Generally, the Alps are dividing Europe into two contrasting climatic zones, in wet north and dry south.

The first archaeobotanical paper on Roman plant husbandry in Serbia appeared in 2008 about Gamzigrad near Zaječar - Felix Romuliana (Medović 2008). Archaeobotanical papers which goal is not only to study Roman plant economy on Serbian soil, but also the barbarian plant economy on the left bank of the Danube River, appear on the annual basis ever since (Dimitrijević \& Medović 2009, Medović 2009, Medović 2010, Medović 2011, Medović 2012).

\section{PLANT REMAINS FROM ROMAN PERI- OD IN SERBIA - THE RIGHT BANK OF THE DANUBE RIVER}

The main crop of the late Roman period at Gamzigrad (second half of the $3^{\text {rd }}-$ second half of the $5^{\text {th }}$ cent. AD) is bread wheat (Triticum aestivum s.l.), while broomcorn millet (Panicum miliaceum), loose six-row barley (Hordeum vulgare subsp. vulgare) and rye (Secale cereale) were also cultivated (Medović 2008). Three pulses could be identified in that period: lentil (Lens culinaris), broad bean (Vicia faba) and common vetch (Vicia sativa). Cultivated fruits are represented with only two grape pipes (Vitis vinifera subsp. vinifera). Wild-fruit gathering was of great importance at Felix Romuliana.

A massive find of barley ( $1^{\text {st }} / 2^{\text {nd }}$ cent. AD) at Gomolava archaeological complex allows us insight into difference between Late Celtic and Roman agriculture (Medović 2010). The change between grain cultivation methods seems to be confirmed - intensive production on small plots has been changed by the extensive agricultural industry of large estates.

At Hissar near Leskovac one botanical sample from Roman period (Medović 2012) has yielded plant remains of broomcorn millet and common walnut (Juglans regia).

Most promising archaeobotanical material from Roman times has been recovered and partially analyzed during Archaeological excavations (2002-2004) at Petrovaradin fortress (Cusum) in
Novi Sad (Medović unpublished). The results will fulfill our knowledge about Roman agricultural practice at the frontier of the empire on the middle Danube. Three major cereals in Roman Cusum were bread wheat, barley and broomcorn millet.

\section{PLANT REMAINS FROM ROMAN PERI- OD IN SERBIA - THE LEFT BANK OF THE DANUBE RIVER}

Two sites on the left bank of the Danube River from the Roman imperial era were archaeobotanicaly investigated: Čurug - "Stari vinogradi" (Medović 2009) and Starčevo - Grad (Medović 2011). This allows us to compare "barbarian" and Roman plant economies on the opposite sides of Danube only partially. So far, only three "barbarian" samples were archaeobotanicaly analyzed.

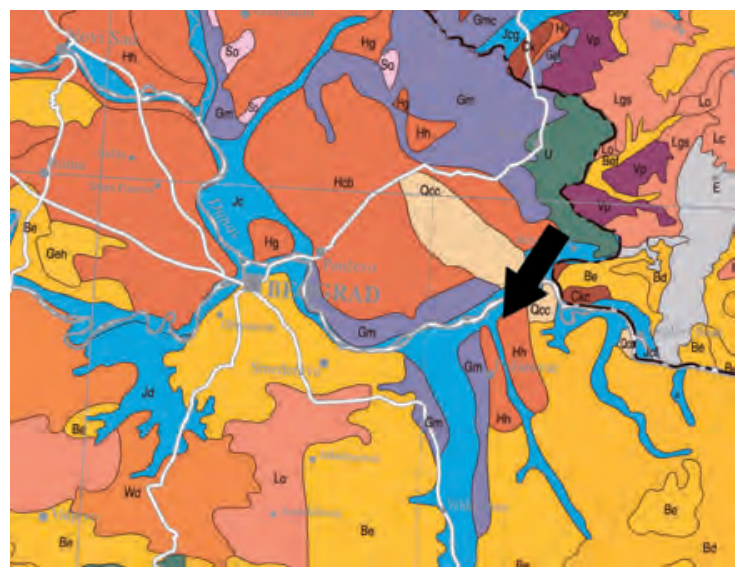

Fig. 2 Soil map of Viminacium area with its location (Anon. 2005). Legend: HhHaplicPhaeozem, HcbCalcaricPhaeozem, HgGleyicPhaeozem, BeEutric Cambisol, Bd Dystric Cambisol, Jc Calcaric Fluvisol.

Beside the mass find of the "unripe" spelt wheat grains (Triticum spelta), grain-storage of Limigants at Curug - "Stari vinogradi" contained also charred items of einkorn wheat (T. monococcum), while emmer wheat (T. dicoccon), loose sixrow barley, rye, bread wheat, broomcorn millet and foxtail millet (Setaria italica) were weedy admixtures. The find also contains 199 charred spikelet forks of mosquitograss (Dasypyrum villosum). More light on the condition of the spelt wheat crop provide the finds of black-bindweed (Fallopia convolvulus) and field bindweed (Convolvulus arvensis). Both weeds are known for "choking" cultivated plants in which they grow. This results in reduced crop yields.

A fair number of carbonized einkorn grains 
rich cereal and weed assemblage (Table 1). The results include five cereals (loose six-row barley, rye, bread wheat, oats and broomcorn millet), and one cultivated pulse crop, lentil. Three fruit species were identified: woodland strawberries (Fragaria vesca), hazel (Corylus avellana) and common fig (Ficus carica). The list of weeds includes 25 plant names.

Is it possible to involve local farmers in the tourism policy of the Archaeological park and persuade them to exclude maize from the crop-rotation? What plants could they use instead? All the archaeological sites mentioned above have one plant in common - broomcorn millet. This plant has been cultivated in the region since Neolithic period and Starčevo culture (Medović 2011). The plant reminds one on a short maize plant. Its hollow stems reach an average height of one meter. The plant has

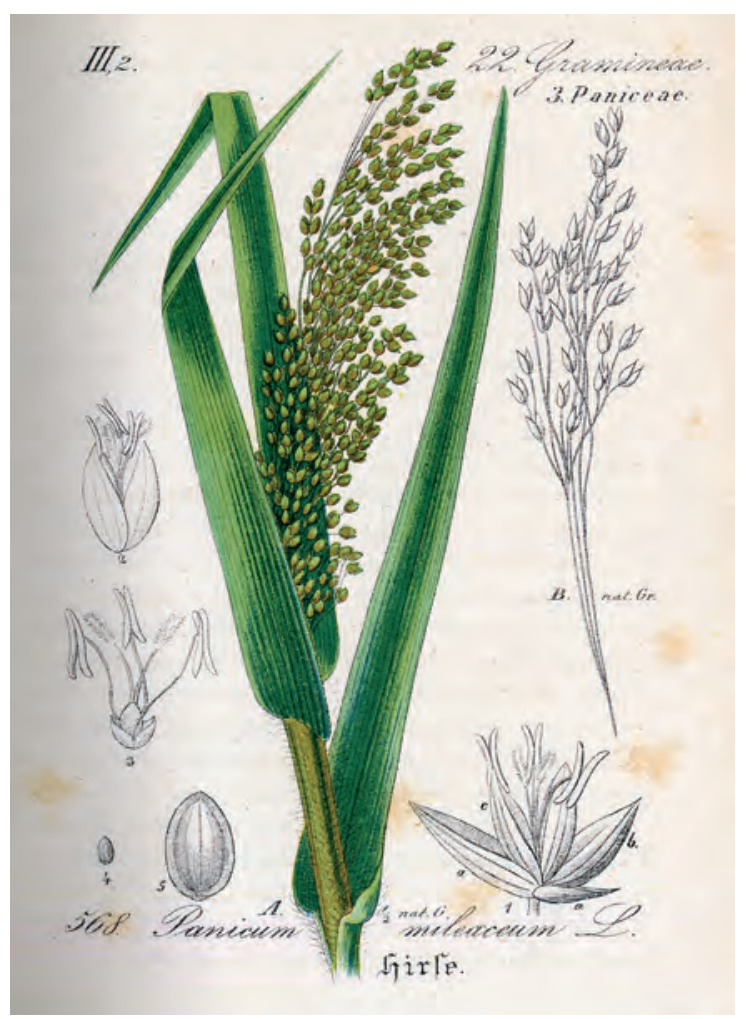

Fig. 4 Broomcorn millet (Hallier 1881).

wide leaves and large, open panicle inflorescence (Fig. 4). Its small seeds even taste like maize - common name for Panicum miliaceum in Serbia is "sitna proja". Its cultivation range approximates the cultivation range of maize. Both plants have the same photosynthetic pathway (C4-plants) which differs from other cere- als. The water requirement of broomcorn millet is probably the lowest of any major cereal. This characteristic and the fact that it will mature in 70 to 90 days from planting make it very interesting for farmers who had experienced severe draughts in the last few years.

Even though it's not possible to remove Kostolac Power plant from the landscape, we can still improve the visual effect of the Archaeological park by providing the authentic indigenous Roman plant production environment. After all, everyone remembers the brilliant scene of Maximus' hand over the barley field in the Ridley Scott's blockbuster Gladiator from the year 2000.

\section{BIBLIOGRAPHY}

\section{Anon 2005}

Soil Atlas of Europe, Luxembourg: European Soil Bureau Network, European Commission.

\section{Dimitrijević, V. \& Medović, A. 2009}

Animal and Plant Remains in a Tomb in Test-Pit $1 / 05$, outside the Fortified Imperial Palace Felix Romuliana, Старинар (н.с.) LVII (2007): 315323.

\section{Hallier, E. 1881}

Flora von Deutschland. Gera-Untermhaus: Verlag von Fr. Eugen Köhler.

\section{Medović, A. 2008}

Gamzigradski ratari - dva koraka napred, jedan korak nazad, Рад Музеја Војводине 50 (2008): 151-173.

\section{Medović, A. 2009}

Čuruški krupnik iz 4. veka - u čvrstom zagrljaju njivskog poponca i njivskog vijušca, Рад Музеја Војводине 51 (2009): 147-157.

\section{Medović, A. 2010}

„Arheoznanje-arheoimanje“ u poseti jednom sremačkom vikusu iz I ili II veka, Рад Музеја Војводине 52 (2010): 101-111.

\section{Medović, A. 2011}

Najbolje iz preistorijske Vojvodine: starčevačka jednozrna pšenica, ,kasna“, i južnobanatski proso, „rani“. Fosilni biljni ostaci sa lokaliteta Starčevo - Grad, Рад Музеја Војводине 53 (2011): 169175. 
Medović, A. 2012

Late Bronze Age Plant Economy at the early Iron Age Hill Fort Settlement Hissar?, Рад Музеја Војводине 54 (2012): 105-118.

Sekulić, P., Ninkov, J., Hristov, N., Vasin, J., Šeremešić, S. \& Zeremski-Škorić, T. 2010 Sadržaj organske materije u zemljištima AP Vojvodine I mogućnost korišćenja žetvenih ostataka kao obnovljivog izvora energije, Ratarstvo i povrtarstvo / Field and Vegetable Crops Research 47 (2010): 591-598.

\section{Tapavički-Ilić, M. \& Arsenijević, M. 2006}

Poljoprivreda centralnog Balkana na prelasku stare u novu eru, Arheologija i prirodne nauke 1 (2006): 111-117.

\section{Zirojević, O. 2006}

Ishrana na Balkanu - orijentalni uticaj, Almanah 33-34 (2006): 77-94.

\section{REZIME}

\section{VIMINACIUM: RIMSKA POLJOPRIVREDA NA SRPSKOM TLU?}

Ključne reči: Viminacium, arheološki park, turizam, arheobotanika, lokalni ratari, antička zemljoradnja.

$\mathrm{Na}$ osnovu rezultata arheobotaničkih analiza dobijenih tokom arheoloških istraživanja na Viminaciumu i ostalim lokalitetima koja su vršena nakon 2000. godine moguće je navesti sve značajnije žitarice koje su bile uzgajane u rimskom periodu na tlu Srbije. Sve ove biljke se i danas mogu videti na našim oranicama, sem jedne - običan proso. Ovaj drevni usev je za svega nekoliko vekova potisnut sa oranica od strane kukuruza. Obe biljke imaju puno sličnosti, počevši od izgleda, preko termina setve, istog procesa fotosinteze, pa čak sve do ukusa. Da li je moguće da ovdašnje ratare uključimo u turističku politiku arheološkog parka i ubedimo ih da iz plodoreda izbace kukuruz i uvrste obični proso? Na ruku nam ide činjenica da je zajedno sa promenom klime poslednjih decenija došlo do pojave sve učestalijih, dugotrajnih suša. Veoma niska potreba za vodom ovog useva kao i činjenica da proso sazreva za svega tri meseca od setve čine ovu biljku veoma interesantnom za poljoprivrednike. Ovo može da bude dobitna kombinacija, kako za posetioce arheološkog parka tako i za same ratare. 